Revista de la red interuniversitaria de estudios sobre las literaturas rioplatenses contemporáneas en Francia

$18 \mid 2018$

El río y la ciudad

\title{
El tiempo del agua
}

\section{Sonia Scarabelli}

\section{OpenEdition}

Journals

\section{Edición electrónica}

URL: http://journals.openedition.org/lirico/5087

DOI: $10.4000 /$ lirico.5087

ISSN: 2262-8339

Editor

Réseau interuniversitaire d'étude des littératures contemporaines du Río de la Plata

\section{Referencia electrónica}

Sonia Scarabelli, «El tiempo del agua », Cuadernos LIRICO [En línea], 18 | 2018, Puesto en línea el 27 septiembre 2018, consultado el 11 mayo 2019. URL : http://journals.openedition.org/lirico/5087 ; DOI : 10.4000/lirico.5087

Este documento fue generado automáticamente el 11 mayo 2019

\section{(c) (i) (9)}

Cuadernos LIRICO está distribuido bajo una Licencia Creative Commons Atribución-NoComercialSinDerivar 4.0 Internacional. 


\section{El tiempo del agua}

\section{Sonia Scarabelli}

Entrar por la Ruta 1 pasando la ciudad de Santa Fe siempre me produce el mismo efecto. Se desanudan los lazos con el tiempo y se anudan otros. Con la naturaleza. Es un efecto; claro, yo lo sé. Como cruzar una especie de puerta. Una cosa -podría decirse- del psiquismo, pero que el cuerpo vive como una fiesta propia. Para mí, la naturaleza es agua, una gran llanura cortada por ríos y arroyos; y a esa altura del norte de la provincia ligeramente acuchillada por momentos-, el agua sobra. El río que corre detrás de la ruta por la que vamos sin verlo es el San Javier. Y este trayecto de la Ruta 1 es lo que yo llamo "el camino a Cayastá". Cayastá es una comuna, y junto a ella está el sitio arqueológico. Allí se fundó por primera vez la ciudad de Santa Fe -después, la Vieja- en el mes de noviembre de 1573. Noviembre, con el calor, la humedad y los mosquitos, en la actual ciudad de Santa Fe, ya es sofocante; noviembre y más al norte... El fundador se llamaba Juan de Garay; y alguien anotó con cierto orgullo en una enciclopedia: "La primera ciudad urbanizada en el Río de la Plata".

De las visitas que hice, me vuelven siempre dos imágenes. El esqueleto del capitán que había perdido a su hija pequeña y que en su testamento dejó orden de que lo enterraran con ella, y una especie de enjambre de colibríes que, al principio, confundí con abejorros; zumbaban enloquecidos sobre las flores abiertas, gigantes comparadas con ellos, de un palo borracho. Me acuerdo, eso sí, del intenso color rosa; me acuerdo del asombro de descubrir que eran colibríes. El palo borracho estaba casi al borde de la barranca muy alta $\mathrm{y}$, en la ribera opuesta, los irupés flotaban serenísimos, pesados y lentos como grandes animales acostumbrados al calor, con sus inmensas flores blancas y el círculo esponjoso que me hacen pensar en una flor de loto, en una flor imaginaria. El lugar del que hablo fue una ciudad al lado de un río. Pasados más de cuatrocientos años, el río San Javier se comió la mitad. Cortó la cuadrícula renacentista como si fuera un pañuelito que doblás al medio, la peló barranca abajo, la hizo desmoronarse como la res del cocinero de la historia de Chuang Tzu. Agua, agua. Quiero acordarme bien de lo que pensé del capitán. Quiero acordarme bien, pero ya se sabe: ¿qué es acordarse de algo? Su esqueleto había descendido hasta quedar casi pegado al de su hija. Pensé en el capitán muerto, al que creía español, mirando vivo un paisaje parecido al que yo veía. Para mí no era extraño, a pesar de septiembre y los más de treinta grados. Para él -pensaba-, habrá sido el infierno, 
un infierno paradisíaco en cierto modo; o un infierno a secas. Padre e hija estaban enterrados en la nave de la antigua iglesia de San Francisco con la cabeza apuntando hacia la puerta, que era como enterraban a los fieles. La cabeza apuntando hacia el altar mayor era un privilegio de los sacerdotes. Los ríos se comen las ciudades, la tierra las cubre, y un día las ruinas salen a la luz, ¿para decirnos qué?

Digo que a ese trayecto lo llamo "el camino a Cayastá" porque, hasta el año pasado, era el único lugar al que me conducía y el único al que me interesaba llegar. Ahora también lo llamo "el camino largo a Las Toscas" -una ciudad ubicada en el extremo noreste de la provincia, casi en el límite con el Chaco-. En octubre de 2017, fue la primera vez que pasé por el Parque Arqueológico Santa Fe la Vieja para seguir de largo. Me quedé con ganas de volver a entrar y caminar entre las ruinas, me quedé con ganas de ver el San Javier. En la ruta, cerca de un parador, nos hablaron de una bajada hermosa. Yo no dejo de pensar nunca en esos anchos ríos americanos, en esos ríos devoradores de ciudades. Pero, a veces, me hace falta sumergirme en el sueño o desvelarme, como ahora, para volver a ver aquello claramente: el otro lado vivo bajo la luz cernida de septiembre y todo vivo, florido incluso, también alrededor de aquella ciudad muerta, desenterrada a medias sobre la barranca y sepultada en el lecho del río quién sabe hasta dónde; recuperada, al fin, por el tiempo del agua. 